\title{
New Imperialism: Towards a Holistic Approach
}

\section{Steven Kettell \& Alex Sutton}

\begin{abstract}
A prominent theme in scholarly analyses of contemporary international affairs concerns the extent to which the unrivalled power and activities of the United States can be said to constitute a form of imperialism. Typically, the contours of this debate centre on the ostensible differences between 'old' and 'new' varieties of imperialist practice. Yet the concept of 'new imperialism' remains one on which little consensus exists. Wide differences of opinion on its origins, dynamics and characteristics are evident, as is an analytical bifurcation between distinct 'economic' and 'geopolitical' explanations. This absence of conceptual unity leads to accounts of new imperialist strategy that are partial, limited and incomplete. If the theoretical value of new imperialism is to be realised, a more holistic approach is needed. To this end, some of the key differences between the contexts of new and old imperialism are explored. The paper concludes that a holistic approach requires an appreciation of imperialism as a strategic choice that springs forth from the intersection of the goals and perceptions held by, as well as the constraints on and opportunities available to, state managers. The distinct environment within which this choice is made provides the novelty of contemporary imperialism, and the particular nature of this environment is further explored in this paper.
\end{abstract}

Keywords: new imperialism, empire, humanitarianism, economics, geopolitics

\section{Introduction}

Imperialism has played a profound role in shaping the world's political and economic systems. Yet despite an initial flourishing of intellectual activity during the early years of the twentieth century, the concept of imperialism has, until recently, been notably absent from mainstream scholarly debates on international affairs. Global developments during the first decade of the twenty-first century, however, have thrust questions of imperialism firmly back into the spotlight. One of the central themes here has been the extent to which the unrivalled power and activities of the United States, and particularly its conduct in the 'war on terror', can be seen to have constituted a form of 'new imperialism'. A central problem in this discussion is that scholars have, as yet, failed to reach any consensus as to what the key features, processes and dynamics of new imperialism actually are, nor how these may differentiate it from its antecedents. Typically, conceptions of new imperialism tend to fall into one of two 'economic' or 'geopolitical' streams of thought, each of which highlight an array of theoretical and empirical concerns. These include the competitive 
pressures of the international market, the machinations of a transnational capitalist class, systemic crises of global capitalism, US economic decline, the prevalence of human rights norms, the security problems posed by rogue states, and the energy needs of the Western world. The purpose of this paper is to critically examine these various accounts, and to suggest ways in which some of the difficulties associated with them may be overcome with a more holistic framework of analysis.

\section{The Historical and Intellectual Development of Imperialism}

The history of imperialism, involving the exertion of sovereignty, control and influence by one state or society over another, has yielded a multitude of forms, the sheer variety of which has impeded attempts at establishing theoretical unity (see, for example: Magdoff, 1978; Mommsen, 1982; Doyle, 1986; Kennedy, 1989; Brewer, 1990; Meiksins Wood, 2005). Indeed, the topography of scholarly analysis reveals a landscape riven with divergence; a lack of consensus on the precise meaning of the term 'imperialism' extending into debates over its causes, mechanics and processes, and yielding deep altercations over its normative merits (Steinmetz, 2005). The plurality of imperial forms invites comparison, and comparisons between the new imperialism, the empires of modernity and the empires of antiquity also have roots in the original studies of colonialism and empire. Furthermore, while these comparisons identify diversity, they also emphasise continuity in the history of empire and imperialism: asserting that the empires that we see today have a great deal in common with the empires of the past. While modern scholars as diverse as Burbank and Cooper (2009), Johnson (2006), Nexon (2008) and Parker (2011) have all argued that the historical development of imperialism is not only synonymous with the historical development of human civilization, but that its scholarly analysis still remains pertinent and revealing, so too did the earliest scholars writing on the subject. As Smith ([1776] 2008:393) remarked, 'the interest which occasioned the first settlement of the different European colonies 
in America and the West Indies, was not altogether so plain and distinct as that which directed the establishment of those of ancient Greece and Rome'. However, one distinction between these earlier scholars, such as Locke, Smith, James and JS Mill, and Marx, and the later scholars beginning with Hobson, is that between colonialism and imperialism. Where earlier scholars made their focus the relationships between 'mother' states and their settler colonies, the 'first wave' of scholars on imperialism focused more specifically on the shift in those relations from mutual benefit to domination, and so too did the focus move from the relationship between the imperial state and its imperial possessions, such as India, to the competitive relationships between empires (Hobson, [1902] 1978:11; Sullivan, 1983:608).

Hobson's ([1902] 1978:11) accumulation theory of imperialism, which built on the work of earlier scholars such as JS Mill ([1848] 1982:735), formed the basis for all future understandings of imperialism and, particularly, Marxist understandings of over-accumulation and over-production leading to imperial expansion. However, even prior to JS Mill's work, Hobson's distinction between colonialism and imperialism rests on James Mill's (1825) understanding of the two. Where colonialism is the migration and settlement of a people to a virgin or sparsely populated land that remains under the government of the 'mother country', imperialism is a perversion of both nationalism and capitalism, an aggressive form of the state geared towards 'territorial and industrial aggrandizement' and transforming the 'wholesome stimulative rivalry of varied national types into the cut-throat struggle of competing empires' (Hobson, [1902] 1978:11).

Reflecting this, general theories of imperialism have spanned a broad conceptual and historical spectrum. The first wave of theories, emerging in the early years of the twentieth century, sought to explain a world in which the dynamics of 'classical' European imperialism were pushing its main protagonists ever-closer to war. A key characteristic here was a view of imperialism as being a product and corollary of capitalism. This, it was argued, created a need for states to secure control over foreign territories, whether to serve the needs of national monopolies or as an outlet for 
'surplus capital' unable to find domestic avenues for profitable reproduction. The outcome was a fatal impulsion towards competition and conflict between the major powers (Bukharin, [1916] 1929; Luxemburg, [1913] 1951; Lenin, [1916] 1963). Alongside these systemic pressures, the early field of study was also shaped by the inclusion of more heterogeneous causal factors, such as the role of sectional interest groups, especially those associated with finance capital (Hobson, [1902] 1978; Hilferding, [1910] 1981), and the impact of socio-cultural forces, such as the enduring influence of pre-capitalist forms of nationalist militarism (Schumpeter, [1918] 1951). A notable division between those regarding capitalism as being inherently conflictual, and those who believed that such tendencies could be tamed by social and political reform, was apparent too with this distinction being most clearly articulated by the dialogue between Kautsky (1914) and Lenin $\left([1916]\right.$ 1963). ${ }^{1}$

The classical European system of empires was shattered by the political, economic and military upheavals that scarred the first half of the twentieth century. These triggered the demise of the Eurocentric world order, led to the onset of decolonisation and facilitated the rise of the United States, unique among nations for its self-image as an anti-imperial power. With the historical tide having taken such an apparently decisive turn against the notion of imperialism, the term, for the most part, was duly pushed out of the scholarly mainstream during the post-1945 era. Moreover, where studies of imperialism continued to be developed, the main focus no longer centred on

\footnotetext{
${ }^{1}$ This debate has continued even into accounts of the new imperialism across economic and geo-political understandings of the phenomenon. Certainly one could argue that economic accounts such as Hardt and Negri (2001), who emphasize the domination of the world market over any particular state, and Kiely (2006) and Callinicos (2010), whose references to a transnational capitalist class, have more in common with Kautsky's notions of ultra-imperialism than Lenin's idea of the last stage of capitalist development. This strand is also present in geo-political understandings of the new imperialism, where authors who stress the importance of human rights and notions of freedom and the capacity of the United States to stabilize the world through its imperialism (Ferguson, 2001; Ignatieff, 2003; Kagan, 1998; Krauthammer, 2001a) also have more in common with Kautsky's argument that imperialism can lead to a stable world order than Lenin's emphasis on inter-imperial rivalry and constant inter-state warfare. Certainly while this is an interesting point of historiography for the study of imperialism, it represents differing accounts of tendencies within imperialism, rather than clearly bifurcated causes and explanations of the existence and practice of imperialism itself.
} 
themes of rivalry and war, but on the changing nature of international capitalism, the qualities of the 'world system', and on questions about economic dependency, underdevelopment and the relations between core and peripheral states (Frank, 1966; Baran and Sweezy, 1968; Galtung, 1971; Mandel, 1975; Wallerstein, 1975; Amin, 1977). Similar themes were evident in non-systemic approaches, where explanations of imperialism highlighted causal factors related to a plurality of contingent socio-cultural, political and economic conditions, both in colonial territories as well as metropolitan centres (see, for example, Gallacher and Robinson, 1953; Fieldhouse, 1966; Doyle, 1986).

During the latter years of the twentieth century the concept of imperialism remained at the academic margins. The dominant scholarly frame, rooted in theories of 'globalisation', now spoke not about the power of the state, but of its 'hollowing-out' in the face of a vigorously expansive world market, a process that many assumed would lead to national political and economic units becoming increasingly subsumed within an undifferentiated global whole (Foster, 2001; Barrow, 2005; Pozo-Martin, 2006). The much-vaunted conceptual resurgence of imperialism during the early years of the twenty-first century was thus as unexpected as it was sudden. Central to this was an assertion that, compared to its forerunners, the contemporary form of imperialism was also both qualitatively distinct and unique. Denoting a figurative as well as a literal shift from 'old' to 'new' imperialism, the view from many quarters was that imperialism was not merely back on the agenda, but that it had now entered an entirely novel and unprecedented phase.

One of the main developments behind this turn of events was the post-Cold War ascension of the United States to a position of international supremacy as the world's sole remaining super- (or hyper-) power. Freed from the constraining embrace of the Soviet Union, it was argued that the US had responded to its historic victory over the USSR by embarking on an expansionary project designed to further extend and enhance its global power through intensified efforts to liberalise the capitalist world economy, and by using its unrivalled military might to advance its geopolitical 
interests. Indeed, one of the key themes in the debate about new imperialism has centred on Washington's apparent transformation into a 'New Rome', an empire analogous to the fallen Republic of antiquity, but one that is unparalleled in its reach, scope and power. As Magdoff and Foster (2002) contend, by the turn of the millennium the world was facing 'a major new development in the history of imperialism', a state of affairs that, as Ignatieff (2003: 2) concurred, had 'no precedent since the days of the later Roman emperors'. Likewise, Steinmetz (2005: 360) maintained that there could be 'little doubt' that the United States stood as 'the controlling center of a global empire'. And as Krauthammer (2001) famously exulted: 'America is no mere international citizen. It is the dominant power in the world, more dominant than any since Rome' (from an exhaustive literature also see Magdoff and Foster, 2001; Chomsky, 2003; Burrach and Tarbell, 2004; Cox, 2004; Bello, 2005; Blum, 2006; Johnson, 2006; Murphy, 2007). One result of this global preeminence was that the principal and almost totally dominant focus of new imperialism was focused on the foreign policy and international relations of the United States. While there are notable exceptions to this, particularly Hardt and Negri (2001) and Shaw (2002:335), these approaches too present either the United States as either holding a privileged position within global capitalism in the former case, or identify, in the latter case, that, while imperialism is a feature of even non-Western states, the international state system is dominated by a 'Western state-conglomerate' with the United States at its centre. ${ }^{2}$

\footnotetext{
${ }^{2}$ Another recent development in the literature has been the further distinction between empire and imperialism, two concepts that are often conflated or used without clear distinction (Mann 2005; Bacevich 2002). Doyle's (1986:7) famous definition that 'empire... is a relationship, formal or informal, in which one state controls the effective political sovereignty of another political society' is a broad and inclusive conception of the relational understanding of empire, and has formed the basis of a number of other works (e.g. Barkey and Hagen 1997; Buttino 1993; Dawisha and Parrott 1997; Motyl 2001). This distinction, however, is a troublesome one. While authors like Doyle (1986) argue that imperialism is the practice or act of creating an empire, other scholars, particularly Marxists (Meiksins Wood 2005; Sutton 2013), contend that while the empires of antiquity offer an insightful analogy of contemporary imperialism, there is a qualitative distinction between the societies within which they exist, and thus the modern and contemporary strategy of imperialism does not necessarily equate to empire. As such, while scholars may reasonably use the term 'empire' as a shorthand to describe the hierarchical organization of the international state system, it is potentially problematic in that it can present the strategy of imperialism,
} 


\section{New Imperialism: Economic Accounts}

Like the topography of imperialism itself, the debate surrounding new imperialism is far from uniform, but comprises a diverse and eclectic field. In this, different conceptual forms and varieties of explanation can be seen to range along a sliding scale; from scholars positing a farreaching and radical shift in global political and economic relations at one end, to those at the other who claim that there has, in fact, been no significant change from the dynamics of old imperialism at all. Within this, studies of new imperialism also display a tendency to cleave into two thematic folds; the core distinction between which being whether its main features are thought to be primarily 'economic' or 'geopolitical' in nature. This is a distinction also made by Callinicos (2010) and Harvey (2003), both of whom, however, remain distinctly committed to economic understandings of imperialism. A principal theme amongst scholars from the former category is that the main characteristics of new imperialism have been ineluctably bound-up with the unprecedented growth in the scale and intensity of the world market since the latter decades of the twentieth century. One of the most prominent schools of thought from this perspective defines new imperialism primarily in terms of global market forces. In one of its most radical variants, Hardt and Negri (2001) contend that global capital itself, having escaped the political confines of the national state, now constitutes a singularly international form of sovereignty, described simply as 'Empire'. Here, contemporary imperialism is thus defined not as the dominance of any particular state, but in terms of the impersonal rule of the world market itself, a universal power beyond the ability of any single government to control. In a similar vein, a second

undertaken by a state, as an institution in the mould of the Roman Empire (as a monolithic organization with centralized control and distinctly one-way relationships) when this is not apparent in contemporary imperial relations at all. The distinction between empire, hegemony and unipolarity also exists within this literature, with Nexon and Wright (2007:253) making a particularly clear argument that empire is qualitatively distinct from both due to the particular pattern of relationships between states in each. 
stream of thought within this category emphasises the notion of a transnational capitalist class. The central assertion here is that the leading global authority is comprised of an international elite (primarily based in, but not limited to, the United States), rather than the abstract power of global capital, and that it is by members of this elite, and in whose interests, that the world economy is duly governed. According to Robinson (2007), one of the main exponents of this thesis, global capitalism is currently entering 'a qualitatively new transnational stage' marked by the rise of globalisation and supranational political and legal institutions, and that what may appear on the surface to be American imperialism is, in reality, a policy used by those members of the transnational elite located within the US state apparatus 'to expand, defend and stabilize the global capitalist system'. At the present time, however, this task is said to be complicated by the emergence of a deep-seated structural crisis within world capitalism; namely (in a reprise of firstwave theories of imperialism), an international over-accumulation of capital resulting from the growing intensity of globalisation. In this context, the increasingly militarist turn of the United States, being conducted most notably under the aegis of the 'war on terror', is seen as one of the core means by which the world's transnational class has sought to resolve this crisis; providing an outlet for surplus American capital, and a way of expanding the world market into previously restricted territories (also see Sklair, 2001; Kiely, 2006; Callinicos, 2010). The third economic approach rejects both the notion of a transatlantic elite, as well as a view of national states being subject to the imperious demands of global capital. This approach argues that the world system remains fundamentally organised by national states, and that the expansion of the world market, rather than diminishing their role, has been orchestrated by the most powerful capitalist states precisely as a means of extending their wealth and influence. In short, the central claim from this perspective is that modern imperial power continues to be rooted in the international state system, but, in contrast to old forms of imperialism, derives not from control over territories but from control over global markets. As Meiksins Wood (2005: Ch.1) explains, the dynamics of new 
imperialism are primarily about 'ensuring that the forces of the capitalist market prevail in every corner of the world', and about 'manipulating those market forces to the advantage of the most powerful capitalist economies'. In this, the position of the United States, as the world's leading capitalist economy and chief beneficiary of an open and liberal world order, is thus of crucial importance. According to Barrow (2005:125), globalisation itself is nothing more than 'a new form of American imperialism', enabling US capital to reshape foreign societies along lines beneficial to American national interests. According to Dumenil and Levy (2004: 660), the principal aim of contemporary imperialism 'is to impose, within the dominated countries, a government prone to the development of economic relations favorable to the interest of dominating countries'.

For scholars taking this approach, a prominent driver behind this process has been a deterioration both in the condition of the US economy and of global capitalism in general (again, typically posed in respect of a systemic crisis of over-accumulation). Here, studies point to a progressive decline in the scale of American economic dominance relative to its main challengers (principally the leading economies of Europe and East Asia) since the 1970s, and to the perilous financial consequences of this slide, notably an enormous rise in the US national debt, from $\$ 909$ billion in 1980 to $\$ 9,985$ billion by 2008 (Office of Management and Budget, 2009: Table 7.1). In this context, the use of American military force is typically seen as something of a rearguard action, as an attempt to prop-up its progressively weakening international position. As Harvey (2003) puts it, while military measures are but 'the tip of the imperialist iceberg', the use of armed force on the part of the United States denotes a growing emphasis on what has now become its last remaining facet of undisputed supremacy (also see Cox, 2004; Dumenil and Levy, 2004; Harvey, 2007). With American military actions being deemed necessary to ensure US control over the world market, a final feature of this perspective also centres on the strategic role of credibility; namely, wielding and applying the effective threat of force as a principal means of preventing any potential transgressors from stepping out of line, and of thereby ensuring that US interests 
prevail. In this respect, as Meiksins Wood (1999) observes, 'frequent displays of military force', far from being anomalous and exceptional, serve an essential demonstrative purpose; reminding the rest of the world that the United States 'can deploy its massive military power any time any place, with or without intelligible reasons, objectives, or strategies' (also see Hobsbawm, 2005).

These economic accounts, which are broadly Marxist in approach, can be split into three separate understandings: a withering of the state, the rejection of 'imperialism' as a state strategy and the emergence of capitalism as an empire unto itself; the identification of a transnational elite, situated particularly in the United States, as the driving force behind the new imperialism to mitigate economic crisis and expand capital accumulation; and a situation of the new imperialism within the international state system and an emphasis upon the control of crucial commodity markets to benefit certain particularly powerful states, and the maintenance of the international capitalist system with the United States as the principal beneficiary of this system.

\section{New Imperialism: Geo-Political Approaches}

While 'economic' accounts of new imperialism focus on the structural dynamics and pressures of contemporary global capitalism and the processes of relative American decline, 'geopolitical' accounts locate its distinguishing features in the changing nature, both ideationally and materially, of the international political sphere. Primarily, this centres on the growth of moral, cultural and legal norms of human rights, and on the security dilemmas posed by the emergence of increasingly disordered territorial zones within the global arena. With the use of military force now eschewed as a legitimate means of settling disputes between the main powers, and with a greater emphasis instead placed on multilateral organisations such as the UN, a defining feature of new imperialism for scholars from this approach is considered to be its use of humanitarian justifications and informal methods of maintaining order (Cooper, 2002; Reid, 2005). In contrast to old imperialism, based to a greater or lesser degree on the enforcement of subordination 
through the use of military power, territorial conquest, direct metropolitan rule and the deployment of ideologies based on racial and cultural supremacy, contemporary imperialism is said to be predominantly characterised by the use of indirect mechanisms, such as diplomacy, finance and trade, and by an ideological commitment to notions of equality, democracy and selfdetermination. As Ignatieff (2003: 1-2) puts it: 'the new empire is not like those of times past, built on colonies and conquest. It is an empire-lite, hegemony without colonies.... without the burden of direct administration and the risks of daily policing'.

For proponents of this view, much stems from the self-declared notion of the United States as constituting a qualitatively different kind of world power; an empire, in the words of Cox (2004: 585), 'without a consciousness of itself as such'. In this formulation, the US is seen as a positive force in the world, providing international goods of peace and security and helping to build stable, effective and democratic state institutions where none previously existed. As Krauthammer (2001a) puts it, the US represents 'a uniquely benign imperium'. Or as Kagan (1998) proclaims, 'the truth is that the benevolent hegemony exercised by the United States is good for a vast portion of the world's population', a form of 'enlightened self-interest that, in practice, comes dangerously close to resembling generosity' (also see Boot, 2001, 2003; Reiff, 1999; Maier, 2002; Rosen, 2003; Bobbit, 2004). From these origins springs the normative correlate that what is needed in the world today is more, not less, American imperialism. As Ferguson (2001) insists, the US needs to recognise the imperiality of its condition and to start acting 'as a global hegemon and make the world a more stable place' (also see Ferguson, 2003, 2008; Donnelly, 2002, Ignatieff, 2003, 2003a).

From this viewpoint, the main driver for imperialist activity today is the need to address the various problems, such as geopolitical disorder and humanitarian crisis, that are posed by failed, unstable or rogue states within the world system. Accordingly, the use of military force is conceived as a form of 'defensive imperialism', a necessary expedient, and one to be deployed 
only as a last resort, for protecting those values to which the US and its Western allies adhere from states that remain committed to acting out of Machiavellian principles. Thus, as Cooper (2002: 16) explains, while it may not be pleasant, it is nevertheless, on occasion, necessary

to revert to the rougher methods of an earlier era - force, pre-emptive attack, deception, whatever is necessary to deal with those who still live in the nineteenth century world of every state for itself. Among ourselves, we keep the law but when we are operating in the jungle, we must also use the laws of the jungle.

Combined with this, geopolitical accounts also commonly maintain that where military action is required, the emphasis is firmly on the need for intervention to be short, rapid and limited in scope. With large-scale and extensive operations likely to appear overtly imperialistic, and to thereby compound anti-US or Western sentiments, the primary objective is to effect an expeditious return to 'normality' with the minimum outlay of manpower, time and finance. Yet this formula also presents a contradiction in that short-term concerns often lead to a downgrading of longer-term issues such as reconstruction and nation-building, and serve to curtail any moves that would involve genuine political reform. As Ignatieff (2003a) notes, the situation remains 'humanitarian in theory but imperial in practice', a condition 'in which states possess independence in name but not in fact'. 'This', he observes, 'is imperialism in a hurry: to spend money, to get results, to turn the place back to the locals and get out'.

Not all commentators, though, are so convinced that the claims made by proponents of new imperialism actually amount to anything new. Rather, for sceptics, the extent of historical difference and novelty that is attributed to contemporary imperial practice is considered to be grossly overstated, with the anti-imperialist ethos of the United States considered little more than a rhetorical illusion designed to mask more generic imperial ambitions and practices. As Kornprobst (2007: 43-6) observes, advocates of benign imperialism ignore 'the dark sides of empire' (namely exploitation, oppression and death); this being merely 'part of a long tradition of 
imperialist literature that aims to justify and glorify the allegedly noble role of the metropolis' (also see Caldwell, 2006). In common with economic accounts of new imperialism, a common theme among sceptics is that the primary objective of the US in recent years has been to sustain its international position in the face of relative decline via the adoption of strategic methods (especially the use of force) designed to ensure control over global oil supplies and to secure leverage over its main challengers and rivals (see Magdoff and Foster, 2001; Eland, 2002; Tabb, 2002; Klare, 2003; Pilger, 2003; Foster, 2006; Johnson, 2006; Pieterse, 2006). From this perspective, the aggressive and overtly expansionary stance adopted by the US during the twenty first century is not thought to reflect a wholesale change in its objectives, but is taken instead as evidence of sustained continuity with the underlying intentions and motives of the American imperium. As Pilger (2003) puts it, the onset of the war on terror merely 'accelerated the continuity of events'. Or as Bose (2007: 92) maintains, the only thing new about contemporary American imperialism is 'the increasing enormity of its military machinery'. Summarising this position, Callinicos (2002: 319) explains: 'The world of imperialism, as it was portrayed by Lenin and Bukharin during the First World War - an anarchic struggle of unequal rivals - still exists, with the United States as first among unequals' (also see Chomsky, 2003; Bello, 2005; Foster, 2006; Khalidi, 2006).

Geo-political accounts can therefore be broadly divided between approaches that emphasise the benign and stabilizing qualities of the new imperialism, embodied in the foreign policy, political ideologies and military interventions of the United States, and those approaches that highlight the more malign qualities of American power, to support its preeminent position in an increasingly competitive state system. The former accounts stress the novelty of a benign empire, while the latter, while identifying novel aspects of this new imperialism, argue that the realpolitik of American imperialism is anything but novel. 


\section{Imperial Strategy in the $21^{\text {st }}$ Century}

While scholarly accounts of new imperialism focus on the unique capacities of the United States in the post Cold War era, as will no doubt be apparent, these accounts are also notable for their lack of consensus on many of the central issues involved. Wide areas of disagreement exist on the causal forces and motivations behind new imperialism (including global capitalist structures, the actions of a transnational elite, the problems of US economic decline, and humanitarian motivations); on the timing of its emergence (this being variously located in the postwar period, the economic crises of the 1970s, the collapse of the Soviet Union and the election of George W. Bush); and on the question of what, exactly, it is (if anything) that makes new imperialism genuinely 'new'. It also remains unclear as to whether 'new imperialism' is meant to denote a new conceptual framework for examining imperialism generally, a new form of imperialism itself, a new strategy for achieving more generic imperial aims, or whether it is instead meant to signify a mix of some, all, or none of these factors (Harvey 2007:57). ${ }^{3}$ Normative issues, too, offer a source of disagreement, with the debate typically operating within the parameters of black or white assessments that serve either as an apologia for US imperialism, overlooking or downplaying its negative effects, or as a means of launching a critical assault on US foreign policy and its malfeasant intentions.

A key problem with existing studies of new imperialism, then, concerns the conceptual framing around mutually exclusive 'economic' or 'geopolitical' factors. While explanations based on the former have frequently overlooked the political aspects of new imperialism, such as the role of humanitarian norms and the security dilemmas posed by failed states, geopolitical accounts have

\footnotetext{
${ }^{3}$ It is also worth noting that there is a general ambiguity in the literature as to what exactly new imperialism refers. While there are studies of other global actors as imperial powers, such as China (see, for example, Ogen, 2008) or the European Union (see, inter alia, Hettne and Soderbaum, 2005; Zielonka, 2008), the overwhelming focus of contemporary imperialism literature is on the power of the United States. Certainly, this is not an unreasonable focus but it is more than likely that future studies of imperialism will expand their empirical scope to include other states and transnational actors. It is therefore the hope of this paper that such future studies will have a holistic framework with which to analyse the emergence of new imperial actors.
} 
similarly tended to bypass the role of economic forces rooted in the internal mechanics of US and global capitalism. This is further reflected in the ambiguous manner with which studies have addressed the relationship between the various structural and agential elements involved in new imperialist practices. The qualities of the former, principally centering on the role of economic structures, have, even on their own terms, remained notably under-theorised (an exception being Harvey, 2003), with most accounts treating this in a descriptive fashion and/or opting to focus instead on aspects that are commensurate with individual agency in terms of the role played by leading political figures or elites (an exception here is Golub, 2004). Consequently, in overemphasising one pole at the expense of the other, existing accounts of new imperialism are unable to adequately account for the full range of dynamics and processes that have underpinned its origins and unfolding, leading to explanatory frameworks that are necessarily partial, limited and incomplete (Chibber, 2004). Though viewing imperialism as an inherent product of capitalistic structures is, as Pieterse (2006: 989) notes, 'much too generalising', as Foster (2006) points out, it likewise remains 'too easy to slide into the crude notion that imperialist expansion is simply a product of powerful groups of individuals who have hijacked a nation's foreign policy to serve their own narrow ends'.

While these issues make it impossible to speak of a single theory of new imperialism, the notion of a new phase in imperialist practice, if not in the more general aims of imperialism itself, nevertheless remains a valuable one for examining the core themes, developments and processes of contemporary international affairs. In order to address the difficulties of extant approaches, however, a more holistic framework of analysis, drawing together both economic and political, as well as structural and agential factors, is therefore required. In conceptual terms, a useful starting point for this involves the relationship between the state, as the world's primary form of political organisation, and the dynamics of the global political-economy, as the over-arching structural context within which states exist and act. Contrary to assertions about the dissolution of the state 
in the face of globalisation, or of the pseudo-omnipotency of a shadowy transnational elite, the central facts of the matter remain that the world system is one that is composed principally of states, that global capitalism itself is structured by and through states, and that states themselves, as well as their interests (or at least as they are conceived by state managers and electorates) are constituted on a national basis (Barrow, 2005). The practically available options that are open to governing officials for promoting these interests at any given moment, then, are delimited both by the 'political' and the 'economic' character of domestic factors, as well as by the broader set of conditions that prevail at the global level. As such, the pursuit of an imperialist strategy, whether it be it 'new' or 'old' in orientation, should not be seen in a deterministic fashion, as the inevitable result or direct product of capitalist pressures, though neither should it be seen as the autonomous and independently construed agency of particular state managers. Rather, the imperialist impulse, and hence the specific form in which it becomes manifest, needs to be examined as a strategic choice; a set of decisions made in the nexus of state managerial goals and perceptions, domestic conditions, and the particular relationship between the state and the wider context of the global environment. The analytical necessity, as Golub (2004: 767) explains, is to 'explore explanatory schemes that shed light on the interplay between the sphere of historic determinations and the sphere of ideas, leaving room for political and ideational autonomy'. The imperialism of the US in the early twenty first century was 'a possible but not a necessary outcome of a new configuration of power, reflecting specific agent agendas in a structuring context'.

This strategic environment has been shaped by a series of profound changes that have taken place during the past few decades. Taken together, these changes denote the main lines of differentiation between the contexts of 'old' and 'new' imperialism, and provide one way of setting out an integrated and more holistic framework of analysis for examining contemporary international affairs. These differences are clearly expressed in several core and interlocking 
dimensions:

- The scale of economic pressures faced by the United States,

- The scope of US global influence,

- The degree of plurality within the international sphere,

- The impact of technological developments,

- The strategic necessity of humanitarian discourse,

- The nature of the 'enemy challenge' faced by the United States, and

- The changing role of military power.

The first of these themes concerns the large-scale transformations that have taken place in the international economic system since the 1970s. While economic forces of one kind or another have been central to the operation of all empires, a key difference in the modern context involves the scale and the intensity of global market pressures, both of which had, by the end of the twentieth century, reached far higher levels than anything ever before experienced. As certain economic accounts have explained, the particular pressures that this has imposed on US policymaking has included the rise of major industrial competitors, such as China, Brazil and India, and the re-emergence of a deep-rooted structural crisis of overproduction, replete with tightening profit margins, downward pressures on wages, and the growth of globally mobile financial capital, the defining leitmotif of 'globalisation' (on this point see Brenner, 2001). This has served to compound the pressure on the US economy, and has placed greater emphasis on the necessity of gaining control over world markets, of expanding their parameters, and of establishing favourable conditions for capital accumulation.

A second key difference between the contexts of new and old imperialism concerns the degree of influence and control that is capable of being exercised by the world's leading power. While many 
previous eras have witnessed periods of unchallenged imperial dominance by a single power (such as Roman or British pre-eminence), the extent of American dominance in the unipolar world following the collapse of the Soviet Union has been without rival. Although the Roman empire at its height may have been able to command control over a greater level of militarised manpower relative to the size of its overall population, the reach, scope, power and technological prowess of the US military machine simply dwarfs anything that has gone before. Described by Golub (2004: 769) as 'a historical singularity', the extent of America's military dominance is reflected in the scale of its military spending; its total outlay amounting to some $40-45 \%$ of the world's total, and equalling the entire military expenditure of the next fifteen countries combined (Rapkin, 2005). As Steinmetz (2005: 362) writes: 'the degree of unipolarity - the military gap between the United States and its contenders - is unprecedented in modern global history'.

A further qualitative distinction between old and new imperialism, and one that serves to limit the scale of US imperial power, is the increased pluralisation of the international sphere. In comparison to the postwar period, let alone the era of classical imperialism, the world of the twenty-first century is a far more variegated political and economic environment. The greater size, intensity and (albeit to a lesser degree) multi-directionality of trade and capital flows, enmeshed with a proliferation of international organisations and agencies, non-governmental actors and pressure groups, as well as an increasing number of independent states themselves, has heightened pressures for inter-state and inter-agency cooperation (be it via multi- or bilateral methods), and has increased the amount of institutional structures to which the US is obliged to engage with, or at least pay some form of lip-service to (Kiely, 2006). The emergence and development of new global powers (such as the European Union and China), as well as regional powers (such as Iran), raise similar questions about the limitations on the freedom of manoeuvre available to U.S state managers. Taken together, these pressures create a series of constraints which, though far from Lilliputian, can nevertheless impinge upon the direction and conduct of 
American imperial strategy. Regardless of the unparalleled degree of power at its disposal, a course of untrammelled unilateralism that attempts to ride roughshod over the entire world will, at the very least (and as clearly seen in the case of the Iraq war), undermine any claims to legitimacy that the US may seek to advance, exacerbate anti-American sentiments and activities, and, in so doing, threaten the overall success of its strategic approach.

The pressures of this pluralisation have also been compounded by technological developments. The principal changes in this dimension relate to the revolution in information technology that has transformed communications from the 1980s, and to the accompanying emergence of new and $24 / 7$ global media outlets and channels. Aided, in part, by the compression and intensification of international economic forces, the main impact of this technological shift has been felt in the greater extent and avidity with which state officials in democratic societies must now seek to manage public opinion, shape the political agenda and direct the flow of sensitive or politically controversial information. The effects of this, however, are dual-sided: exposing state managers to information flows that are beyond their ability to control and forcing them to present and defend their actions in such a way as to be amenable to public concerns and values; but, at the same time, opening-up opportunities for officials to actively shape the discursive landscape and to frame key issues in ways that are ultimately favourable to the pursuit of their goals (see for example Savigny, 2002).

These changes in the international context themselves combine to produce a fifth discernible difference between the worlds of old and new imperialism; namely (as highlighted by geopolitical accounts), increased pressure on state authorities to adhere to a discursive framework rooted in humanitarian values and principles. While such assertions have long been a prevalent feature of imperial strategies, forming, as Eland (2002: 3) notes, 'one of the recurring themes of empires throughout history', a core difference today is the extent to which legal and cultural norms of human rights have become embedded in the landscape of international politics, establishing 
what Cooper (2002: 13) describes as a prevailing 'moral consciousness'. As such, the extent to which humanitarian justifications are now required in order for any legitimacy to be conferred upon imperialist interventions (especially those of the military variety), are far greater than at any previous point in history.

The effects of this ideological transformation, as with the impact of technological change, are also dual-sided. On the one hand, effectively placing imperial strategy within a discursive framework of human rights and democratic norms can go a long way to ensuring acquiescence for other, more generic imperial aims. As Ayers (2009) points out, the discourse of 'democratisation' is typically driven in support of the formal right to representation within a liberal free market democracy (rather than, say, more positive social and economic rights). Or, as Neep (2004) observes: 'The democracy card is immensely useful for the United States to play', containing 'a number of different values, meanings and significances that can be used to fit a variety of policy objectives'. On the other hand, however, embedding imperial activities within a humanitarian discourse also contains inherent dangers. Given that the ultimate objectives of any imperialist strategy are, by definition, designed to serve the particular interests of the metropole rather than the humanitarian interests of the imperialised, and given that, as such, the practical results are unlikely to match the loftiness of any espoused objectives, the eventual outcomes, should any discrepancy between the rhetoric and the reality become clear, are likely to undermine any claims to ethical motivations, and to thereby erode and delegitimise the imperial project (Bello, 2006).

A further influence on the character of contemporary imperialism involves the primary 'enemy challenge' to the US itself. In stark contrast to the threats posed by territorially fixed and defined states (such as that presented by the Soviet Union), or from groups of people that are defined, more or less, in terms of ethnicity (such as the threats to the integrity of the Roman empire posed by groups such as the Gauls, Huns and Goths), the disaggregated and dispersed threat from 
radical Islamic terrorism, as well as by unstable, failed and rogue states, at the beginning of the twenty-first century, is both taxonomically and qualitatively unique. While the challenge posed may not be of the same existential order of magnitude as that raised by a direct invasion or Cold War nuclear armageddon, the risks to America's economic and geopolitical interests are nevertheless significant, and the available options for dealing with the issue remain highly problematic. For one thing, attempting to use military force in all possible countries, regions or scenarios in which an actual or potential threat to US interests might conceivably exist would be highly unlikely to succeed, and, moreover, would be likely only to prove a costly means of exacerbating anti-Americanism and of thereby fuelling further dangers. Indeed, as Ignatieff (2003: 2-3) astutely notes: 'The war on terror is risky because it appears to require the exercise of American power everywhere at once' (also see Eland, 2002; Boot, 2003).

The final distinguishing feature of new imperialism, then, concerns the strategic role of military force itself. One of the key cumulative effects of the interlocking dimensions set out here has been to generate strong systemic pressures pushing in the direction of small, flexible and limited military operations; a 'military lite' approach that stands in overt contrast to previous imperial strategies with an emphasis on conquest and the large-scale deployment of manpower. Economic pressures, for example, have placed a greater emphasis on costs, and have thus helped to create a desire to avoid open-ended and expensive projects (especially where these might involve assuming direct burdens of territorial administration), the cultural-legal prevalence of humanitarian norms, the pressures of managing public opinion and the dangers of stoking greater levels of anti-American sentiments also mitigate against prolonged and overtly imperialist enterprises, while the dispersed and decentred nature of the threat to the US places a greater premium on retaining a capacity to effectively police the world system as a whole, as opposed to devoting resources too intensively to one particular country or region. In combination, and as is well noted by economic, geopolitical and sceptical accounts alike, these conditions have 
also created a heightened strategic need for credibility. As the inability of the United States to deal directly with every possible deviant, threat or challenger has grown, so too has the importance of being able to avoid having to deploy military force by being credibly willing to do precisely that.

Conceived as a whole, these various dimensions, which form the main contextual landscape of new imperialism, illustrate a further important point: that the contemporary imperialism of the US does not constitute a clearly delineated break from the past, but, rather, contains elements of continuity with, as well as change from, previous imperial forms (Steinmetz, 2005). Many of those features that are often considered to be 'new' about new imperialism, then, are not of-themselves qualitatively unique and distinct, but are characteristics that denote an intensification, an extension and a sharpening of pre-existing trends and features of earlier imperialist forms. At the same time, while the sceptical claim that new imperialism merely seeks to achieve generic imperial goals based around shaping the global political and economic environment in the interests of the imperial centre is a valid one, this should not be taken to mean that no significant change has taken place. Rather, what has been central in the shift from old to new imperialism has been the way in which these imperial goals are achieved. In this sense, 'new' imperialism signifies a change in the means, if not the ends, of imperial practice.

\section{Conclusions}

Debates around new imperialism are founded on the notion that the end of the Cold War and the collapse of Communism transformed the United States into a singularly dominant global empire, and turned Washington into a New Rome. Yet the conceptual framework of new imperialism is one that is without consensus and contains a number of divergent interpretations. Divided between 'economic' and 'geopolitical' explanations, scholarly analyses emphasise a range of divergent features, processes and dynamics, including increased levels of global competition, the 
actions of a transnational elite, crises of overproduction, American economic decline, the growth of human rights norms and security dilemmas. The fragmented nature of these approaches yields limited and partial explanatory frameworks based on narrow and exclusionary themes.

Considered holistically, however, the core issues raised by such analyses offer a useful means of understanding events during the first decade of the twenty-first century. Indeed, the reconciliation of these approaches presents an opportunity to provide a sophisticated and inclusive understanding of imperialism in the $21^{\text {st }}$ Century, which incorporates the observed features of the phenomenon without dismissing any of them as mere ephemera, or as superficial elements of a more fundamental problem. Although not signifying a sharply delineated break from previous imperial practices, the central factors and pressures of the new imperialist context, including the drive to secure control over world markets, the necessity of dealing with a more pluralised international sphere, a greater emphasis on humanitarian discourse, the changing nature of the threat to the US empire, the establishing of credibility, and so on, have arguably produced a qualitatively different form of imperial strategy from the United States than that pursued by imperial powers previously. These imperial practices have to be considered, above all, in terms of the strategic decisions made by state managers and the national and international, economic and geo-political conditions that lead to their consideration and implementation. In order to capture the internal processes and dynamics of this strategy more accurately, a more comprehensive analytical framework for understanding new imperialism is required. The suggestions detailed here might go some way to illustrating how such approach may be constructed.

\section{References}

Amin, S. (1977), Imperialism and Unequal Development, Monthly Review Press, New York. 
Ayers, A. (2009), 'Imperial liberties: democratisation and governance in the 'new' imperial order', Political Studies, 57(1): 1-27.

Bacevich, A. (2002), American Empire: The Realities and Consequences of U.S. Diplomacy, Harvard University Press, New Haven.

Baran, P. A. and Sweezy, P. A. (1968), Monopoly Capital: An Essay on the American Economic and Social Order, Penguin, Harmondsworth.

Barkawi, T. and Laffey, M. (2002), 'Retrieving the imperial: empire and international relations', Millennium, 31(1): 109-127.

Barkey, K. and Hagen, M. (1997), After Empire: Multiethnic Societies And Nation-building: The Soviet Union And The Russian, Ottoman, And Habsburg Empires, Westview Press, New York.

Barrow, C. W. (2005), 'The return of the state: Globalization, state theory, and the new imperialism', New Political Science, 27(2): 123-145.

Beitel, K. (2005), 'The US, Iraq and the future of empire', Historical Materialism, 13(3): 163-192.

Bello, W. (2005), Dilemmas of Domination: The Unmaking of the American Empire, Zed, London.

Bello, W. (2006). 'Humanitarian intervention: evolution of a dangerous doctrine', Focus on the Global South, 19/1/06.

Biddle, S. (2002), 'The new way of war?', Foreign Affairs, May/June.

Blair, T. (2002), 'The power of world community', in Re-Ordering the World. Foreign Policy Centre.

Blum, W. (2006), Rogue State: A Guide to the Word's Only Superpower, Zed, London.

Bobbit, P. (2004), 'Better than empire', Financial Times, 13/3/04. 
Boot, M. (2001), 'The case for American empire', The Weekly Standard 7(5).

Boot, M. (2003), The Savage Wars of Peace: Small Wars and the Rise of American Power, Basic, New York.

Bose, P. (2007), "New' imperialism? on globalisation and nation-states', Historical Materialism, 15(3): 95-120.

Brenner, R. (2001), 'The world economy at the turn of the millennium: towards boom or crisis?' ism?, Review of International Political Economy, 8(1): 6-44.

Brenner, R. (2006), 'What is, and what is not, imperialism?', Historical Materialism, 14(4): 79-105.

Brewer, A. (1990), Marxist Theories of Imperialism: A Critical Survey, Second Edition, Routledge, London.

Bromley, S. (2005), 'The United States and the control of world oil', Government and Opposition, 40(2): $225-255$.

Bukharin, N. ([1916] 1929), Imperialism and World Economy, International Publishers, London.

Burbank, J. and Cooper, F. (2009), Empires in World History: Power and the Politics of Difference, Princeton University Press, Princeton.

Burrach, R. and Tarbell, J. (2004), Imperial Overstretch: George W. Bush and the Hubris of Empire, Zed, London.

Buttino, M. (1993), In a Collapsing Empire: Underdevelopment, Ethnic Conflicts and Nationalisms in the Soviet Union, Feltrinelli, Rome.

Caldwell, A. (2006), 'Empire and exception', New Political Science, 28(4): 489-506.

Callinicos, A. (2002), 'The actuality of imperialism', Millennium, 31(2): 319-326. 
Callinicos, A. (2010), Imperialism and Global Political Economy, Polity, Cambridge.

Chesnais, F. (2007), 'The economic foundations of contemporary imperialism', Historical Materialism, 15(3): 121-142.

Chibber, V. (2004), 'The return of imperialism to social science', European Journal of Sociology, 45(3): 427-441.

Chomsky, N. (2003), Hegemony or Survival: America's Quest for Global Dominance, Penguin, London.

Chomsky, N. (2003b), 'Telling the truth about imperialism', interview with Noam Chomsky, International Socialist Review, November-December, 2003.

Chomsky, N. (2008), 'Humanitarian imperialism: the new doctrine of imperial right', Monthly Review, 6o(9).

Cooper, R. (2002), 'The Post Modern State', Re-Ordering the World, Foreign Policy Centre.

Cox. M. (2004), 'Empire, imperialism and the Bush doctrine', Review of International Studies, 30(4): $585-608$.

Cox. M. (2005), 'Empire by denial: the strange case of the United States', International Affairs, 81(1): 15-30.

Cox, R. (2004), 'Beyond empire and terror: critical reflections on the political economy of world order', New Political Economy, 9(3): 307-323.

Dawisha, K. and Parrott, B. (eds.) (1997), The End of Empire?: The Transformation of the USSR in Comparative Perspective, M E Sharp, New York.

Donnelly, T. (2002), 'The past as prologue: an imperial manual', Foreign Affairs, July/August. 
Doyle, M. W. (1986), Empires, Cornell University Press, Ithaca.

Dumenil, G. and Levy, D. (2004), 'The economics of US imperialism at the turn of the 21st century', Review of International Political Economy, 11(4): 657-76.

Eland, I. (2002), 'The empire strikes out: the "new imperialism" and its fatal flaws, Policy Analysis, No.459: 1-127.

Eland, I. (2008), 'A counterproductive "war on terror"', Middle East Online, 27/4/08.

Ferguson, N. (2001), 'The US must make the transition from informal to formal empire', Guardian, 31/10/01.

Ferguson, N. (2003), 'The empire that dare not speak its name', SundayTimes, 13/4/03.

Ferguson, N. (2008), Colossus: The Rise and Fall of the American Empire, Penguin, London.

Fieldhouse, D. K. (1966), The Colonial Empires: A Comparative Survey from the Eighteenth Century, Weidenfeld and Nicolson, London.

Foster, J. B. (2001), 'Imperialism and "empire"', Monthly Review, 53(7).

Foster, J. B. (2006), 'The new geopolitics of empire', Monthly Review, 57(8).

Frank, A. G. (1966), The Development of Underdevelopment, MRP, New York.

Gallagher, J. and Robinson, R. (1953), 'The imperialism of free trade', Economic History Review, $\mathrm{VI}(1)$.

Galtung, J. (1971), 'A structural theory of imperialism', Journal of Peace Research, 81(8): 81-117.

Golub, P. (2004), 'Imperial politics, imperial will and the crisis of US hegemony', Review of 
International Political Economy, 11(4): 763-86.

Hardt, M. and Negri, A. (2000), Empire, Harvard University Press, London.

Harvey, D. (2003), The New Imperialism, Oxford University Press, Oxford.

Harvey, D. (2007), 'In what ways is "the new imperialism" really new?', Historical Materialism, 15(3): 56-70.

Hettne, B. and Soderbaum, F. (2005), 'Civilian Power or Soft Imperialism? EU as a Global Actor and the Role of Interregionalism', European Foreign Affairs Review, 10(4)

Heuer U-J, and Schirmer, G. (1998), 'Human rights imperialism', Monthly Review, 49(10).

Hilferding, R. ([1910] 1981), Finance Capital: A Study of the Latest Phase in Capitalist Development, Routledge, London.

Hobsbawm, E. (2005), 'The New Imperialism', Guardian, 26/6/05.

Hobson, J. A. (1978), Imperialism: A Study, University of Michigan Press, Michigan.

Hopkins, A. G. (2007), 'Capitalism, nationalism and the new American empire', Journal of Imperial and Commonwealth History, 35(1): 95-117.

Ignatieff, M. (2003), Empire Lite: Nation-Building in Bosnia, Kosovo, Afghanistan, Vintage, London.

Ignatieff, M. (2003a), 'The Challenges of American imperial power', Naval War College Review. $\mathrm{LVI}(2)$.

Ignatieff, M. (2003b), 'The American empire: the burden', New YorkTimes, 5/1/03.

Ikenberry, G, J. (2002), 'America's imperial ambition', Foreign Affairs, September/October. 
Ikenberry, G. J. (2004), Illusions of empire: defining the new American order, Foreign Affairs, March/April.

Ikenberry, G. J. (2005), Power and liberal order: America's postwar world order in transition, International Relations of the Asia-Pacific, 5(2): 133-152.

Johnson, C. (2006), The Sorrows of Empire: Militarism, Secrecy, and the End of the Republic. Verso, London.

Kagan, R. (1998), 'The benevolent empire', Foreign Policy. No.111.

Kagan, R. (2003), Paradise and Power: America and Europe in the New World Order, Atlantic, London.

Kautsky, K. (1914), 'Ultra-Imperialism', Die Neve Zeit, September 1914.

Kennedy, P. (1989), The Rise and Fall of the Great Powers, Vintage, London.

Khalidi, R. (2006), 'Iraq and American empire', New Political Science, 28(1): 125-134.

Kiely, R. (2006), 'United States hegemony and globalisation: what role for theories of imperialism?', Cambridge Review of International Affairs, 19(2): 205-221.

Klare, M. (2003), 'The new geopolitics', Monthly Review 55(3).

Kornprobst, M. (2007), 'Comparing apples and oranges? leading and misleading uses of historical analogies', Millennium: Journal of International Studies, 36(1): 29-49.

Krauthammer, C. (2001), 'The Bush Doctrine', Time, 5/3/01.

Krathammer, C. (2001a), 'The Bush doctrine: ABM, Kyoto and the new American unilateralism', The Weekly Standard 6(36). 
Lenin, V. I. ([1916] 1963), Imperialism, the Highest Stage of Capitalism, Progress, Moscow.

Luxemburg, R. ([1913] 1951), The Accumulation of Capital, Routledge and Kegan Paul, New York.

Magdoff, H. (1978), Imperialism: From the Colonial Age to the Present, Monthly Review Press, London.

Magdoff, H. and Foster, J. B. (2001), '2001 after the attack ... the war on terrorism', Monthly Review, 53(6).

Magdoff, H. and Foster, J. B. (2002), 'U.S. imperial ambitions and Iraq', Monthly Review, 54(7).

Maier, C. S. (2002), 'An American empire? the problems of frontiers and peace in twenty-firstcentury world politics', Harvard Magazine, November-December: 28-31.

Mandel, E. (1975), Late Capitalism, New Left Books, London.

Mann, M. (2005), Incoherent Empire, Verso, London.

Meiksins Wood, E. (1999), 'Kosovo and the new imperialism', Monthly Review, 51(2).

Meiksins Wood, E. (2005), Empire of Capital, Verso, London.

Mill, J.S. ([1848] 1982), Collected Works of John Stuart Mill, Toronto University Press, Toronto.

Mill, James (1825), Essays on Government, Jurisprudence, Liberty of the Press and Law of Nations, London.

Mommsen, W, J. (1982), Theories of Imperialism, University of Chicago Press, Chicago.

Motyl, A. (2001), 'Is Everything Empire? Is Empire Everything?', Comparative Politics, 38(2)

Murphy, C. (2007), The New Rome: The Fall of an Empire and the Fate of America, Icon, London. 
Neep, D. (2004), 'Dilemmas of democratization in the Middle East: the 'forward strategy of freedom", Middle East Policy, 11(3).

Nexon, D. (2008), 'What's this then? "Romanes Eunt Domus?"', International Studies Perspectives, 9

Nexon, D. and Wright, T. (2007), 'What's at Stake in the American Empire Debate', American Political Science Review, 101(2)

Ogen, O. (2008), 'Contemporary China-Nigeria Economic Relations: Chinese Imperialism or South-South Mutual Partnership?', Journal of Current Chinese Affairs, 37(3)

Parker, N. (2010), 'Empire as a Geopolitical Figure', Geopolitics, 15

Parker, N. (2011), 'Imperialism, Territory, and Liberation: on the Dynamics of Empire Stemming from Europe', Journal of Political Power, 4(3)

Pieterse, J. N. (2006), 'Beyond the American bubble: does empire matter?', Third World Quarterly, 27(6): $987-1002$.

Pilger, J. (2003), The New Rulers of the World, Verso, London.

Pozo-Martin, G. (2006), 'A tougher Gordian knot: globalisation, imperialism and the problem of the state', Cambridge Review of International Affairs, 19(2): 223-242.

Rapkin, D. P. (2005), 'Empire and its discontents', New Political Economy, 10(3): 389-411.

Reid, J. (2005), 'The biopolitics of the war on terror: a critique of the "return of imperialism" thesis in international relations', Third World Quarterly, 26(2): 237-252.

Rieff, D. (1999), 'A new age of Liberal imperialism?', World Policy Journal, 16(2): 1-10. 
Robinson, W. I. (2007), 'Beyond the theory of imperialism: global capitalism and the transnational state', Societies Without Borders 2(1): 5-26.

Rosen, S. R. (2003), 'An Empire if you can keep it', The National Interest, No.71: 51-61.

Schumpeter, J. ([1918] 1951), 'Sociology of Imperialism', in Imperialism and Social Classes , Meridian, New York.

Shaw, M. (2002), 'Post-Imperial and Quasi-Imperial: State and Empire in the Global Era', Millennium, 31(327)

Sklair, L. (2001), The Transnational Capitalist Class, Blackwell, Oxford.

Steinmetz, G. (2005), 'Return to empire: the new U.S. imperialism in comparative historical perspective', Sociological Theory, 23(4).

Stokes, D. (2005), 'The heart of empire? theorising US empire in an era of transnational capitalism', Third World Quarterly, 26(2): 217-236

Smith, A. ([1776] 2008), The Wealth of Nations, Oxford Paperbacks, Oxford.

Straw, J. (2002), 'Order Out of Chaos: The Challenge of Failed States', in Re-Ordering the World. Foreign Policy Centre.

Sullivan, E.P. (1983), 'Liberalism and Imperialism: JS Mill's Defence of the British Empire', Journal of the History of Ideas, 44(4)

Sutton, A. (2013), 'Towards an open Marxist Theory of Imperialism', Capital and Class, 37:2

Todd, E. (2003), After the Empire: The Breakdown of the American Order, Constable, London.

Wallerstein, I. (1975), World Inequality: Origins and Perspectives on the World System, Spokesman, Nottingham. 
Zielonka, J. (2008), 'Europe as a Global Actor: Empire by Example?', International Affairs, 84(3) 